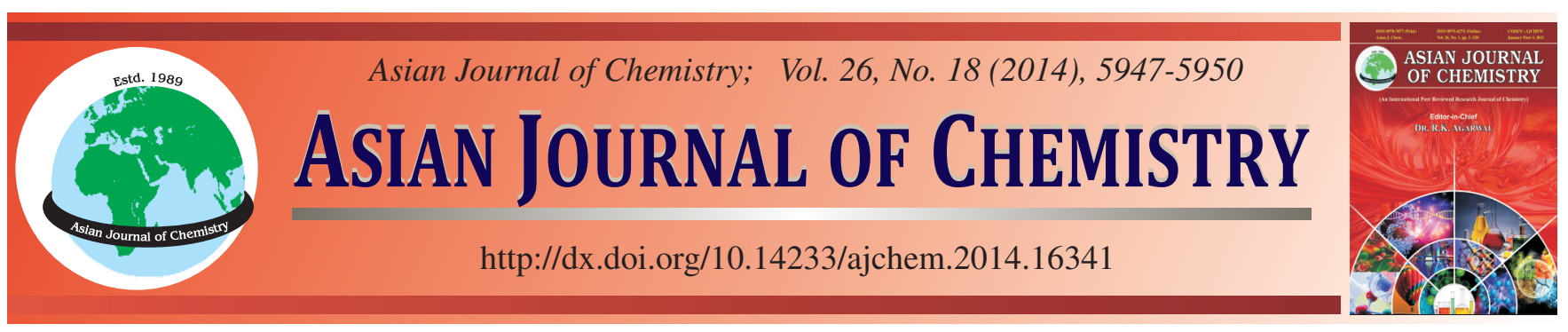

\title{
QSAR Studies of Biological Activity with Phenylpropyl Aldehyde Thiosemicarbazone Compounds
}

\author{
Hui-Min Bi ${ }^{1, *}$, Jun-Ping Hu ${ }^{1}$, Fu-Ying You ${ }^{1}$, Meng-Meng GaO ${ }^{1}$ and Chun-Hua Dong ${ }^{1,2}$
}

${ }^{1}$ Handan Key Laboratory of Organic Small Molecule Materials, Handan College, Hebei 056002, Handan, P.R. China

${ }^{2}$ Institute of Chemistry, Chinese Academy of Sciences, Beijing 100190, P.R. China

*Corresponding author: E-mail: binbi99@163.com

Published online: 1 September 2014;

AJC-15829

We have selected 15 phenylpropyl aldehyde thiosemicarbazone compounds to study the structure-activity relationship. The theoretical
parameters were calculated by HF method in 6-31g* level, The study finds that, there are certain relevance between the antibacterial
activity of the compounds and the HOMO and LUMO. The mechanism may be that, the compounds receive electrons from the receptors
when the compounds mixes with the receptors. Then we established mathematical correlation between the properties and bioactivity of
these compounds. It could give some clues for further molecular designing to future workers.
Keywords: Phenylpropyl aldehyde, Thiosemicarbazone, Structure-activity, Relationships, Quantum chemistry.

\section{INTRODUCTION}

The phenylpropyl aldehyde thiosemicarbazone compounds have biologically active in a wide range, such as antibacterial, antifungal, antituberculosis, antiviral, antitumor, antiparasitic and antimalarial and other bioactivity ${ }^{1-5}$. They have also attracted wide attention in pesticide industry. Through the test of these compounds, it is found that these compounds have inhibited activity to bollworm tyrosinase significantly, they have good economic value and practical value ${ }^{6-8}$.

$\mathrm{Xu}$ et al. ${ }^{9}$ had synthesized 15 phenylpropyl aldehyde thiosemicarbazone compounds (Fig. 1) and detected the biological activity. We calculated the stable structures and properties parameters of these molecules and study the correlation between the biological activity of these compounds and structural parameters.<smiles>[R]c1ccc(CC/C=N/NC(N)=S)cc1</smiles>
a: $\mathrm{R}=\mathrm{H}$
d: $R=2,4-\mathrm{Cl}_{2} \quad \mathrm{~g}: \mathrm{R}=3-\mathrm{Br}$
j: $\mathrm{R}=3-\mathrm{OCH}_{3}$
m: $\mathrm{R}=4-\mathrm{OC}_{2} \mathrm{H}_{5}$
b: $\mathrm{R}=2-\mathrm{Cl} \quad$ e: $\mathrm{R}=2-\mathrm{NO}_{2} \quad \mathrm{~h}: \mathrm{R}=4-\mathrm{F}$
k: $\mathrm{R}=4-\mathrm{OCH}_{3}$
n: $\mathrm{R}=4-\mathrm{CH}_{3}$
c: $\mathrm{R}=4-\mathrm{Cl} \quad \mathrm{f}: \mathrm{R}=4-\mathrm{NO}$

Fig. 1. Structures of compounds

\section{EXPERIMENTAL}

The geometries of all compounds were optimized using the ab initio HF with the $6-31 G^{*}$ basis set. Harmonic vibrational frequencies calculated at the same level were used for characterization of stationary points as a minimum. All quantum calculations were performed with the Gaussian 03 program.

\section{RESULTS AND DISCUSSION}

Parameters: The result of quantum calculation was listed in Table-1.

The energy, main composition and proportion of the frontier molecules orbitals: According to the theory of molecular orbital (MO), the highest occupied molecular orbital (HOMO) and the lowest unoccupied molecular orbital (LUMO) have the greatest influence on the activity of compounds. The reaction between active molecule and receptor macromolecular operated on the frontier molecules orbitals. $\mathrm{E}_{\text {Hомо }}$ is the energy of HOMO, which relate to the ability of electron donor. $\mathrm{E}_{\mathrm{LUMO}}$ is the energy of LUMO, which relate to the ability of acceptance of electronic. For molecules of medicine, too low- $\mathrm{E}_{\mathrm{LUMO}}$ or too high- $\mathrm{E}_{\text {Hомо }}$ means that the of activity molecule is too strong, it is easy to be metabolized in organism. The effect of medicine is difficult to control, so the $\mathrm{E}_{\mathrm{LumO}}$ or $\mathrm{E}_{\text {номо }}$ of the medicine molecule should be suitable to estimate expected value ${ }^{10-12}$.

From Table-2, the difference of $\mathrm{E}_{\text {номо }}$ of these compounds is small and the difference of $\mathrm{E}_{\mathrm{LUMO}}$ of these compounds is 
TABLE-1

PARAMETERS OF COMPOUNDS

\begin{tabular}{|c|c|c|c|c|c|c|c|c|c|c|}
\hline Compd. & $\mathrm{E}_{\text {Номо }}$ & $\mathrm{E}_{\mathrm{LUMO}}$ & $\mathrm{E}_{\text {Total }}$ & $\mu$ & $\mathrm{P}$ & M & V & $S(G)$ & $\log \mathrm{P}$ & $\mathrm{R}$ \\
\hline $\mathbf{a}$ & -0.3053 & 0.0804 & -0.2249 & 6.718 & 24.91 & 207.29 & 674.86 & 433.62 & 2.42 & 66.02 \\
\hline b & -0.3052 & 0.1203 & -0.1848 & 7.619 & 26.84 & 241.74 & 712.09 & 447.78 & 2.94 & 70.83 \\
\hline c & -0.3078 & 0.1152 & -0.1926 & 4.565 & 26.84 & 241.74 & 724.28 & 466.11 & 2.2 & 70.74 \\
\hline d & -0.3217 & 0.1072 & -0.2145 & 4.387 & 28.51 & 276.18 & 760.36 & 474.99 & 2.91 & 68.86 \\
\hline e & -0.3054 & 0.0588 & -0.2465 & 9.167 & 26.75 & 252.29 & 723.09 & 455.52 & -1.42 & 71.53 \\
\hline f & -0.3126 & 0.0546 & -0.2580 & 1.266 & 26.75 & 252.29 & 732.61 & 463.81 & -2.26 & 71.24 \\
\hline g & -0.3065 & 0.1167 & -0.1898 & 5.730 & 27.53 & 286.19 & 737.83 & 466.27 & 2.47 & 73.56 \\
\hline h & -0.3073 & 0.1191 & -0.1883 & 4.950 & 24.82 & 225.28 & 683.99 & 439.1 & 1.82 & 66.15 \\
\hline i & -0.3030 & 0.1312 & -0.1717 & 7.416 & 27.38 & 237.32 & 746.17 & 465.63 & 2.17 & 72.49 \\
\hline $\mathbf{j}$ & -0.3042 & 0.1282 & -0.1760 & 8.065 & 27.38 & 237.32 & 751.04 & 473.52 & 2.39 & 70.04 \\
\hline $\mathbf{k}$ & -0.3045 & 0.1269 & -0.1777 & 7.272 & 27.38 & 237.32 & 749.71 & 475.71 & 2.39 & 70.04 \\
\hline I & -0.3009 & 0.1346 & -0.1663 & 8.386 & 29.85 & 267.35 & 822.09 & 512.76 & 2.14 & 76.5 \\
\hline $\mathbf{m}$ & -0.3044 & 0.1270 & -0.1774 & 7.429 & 29.21 & 251.35 & 801.26 & 504.97 & 2.74 & 74.79 \\
\hline $\mathbf{n}$ & -0.3047 & 0.1272 & -0.1775 & 7.062 & 26.74 & 221.32 & 728.63 & 462.04 & 3.11 & 68.62 \\
\hline o & -0.3047 & 0.1272 & -0.1775 & 7.051 & 30.41 & 249.37 & 826.39 & 514.01 & 3.84 & 77.77 \\
\hline
\end{tabular}

TABLE-2

ENERGY OF THE MOLECULAR FRONTIER ORBITALS

\begin{tabular}{|c|c|c|c|c|c|c|c|c|c|}
\hline Compd. & $\mathrm{E}_{\text {Номо }}$ & $\mathrm{E}_{\mathrm{LUMO}}$ & $\mathrm{E}_{\text {Total }}$ & $\Delta \mathrm{E}$ & Compd. & $\mathrm{E}_{\text {Номо }}$ & $\mathrm{E}_{\mathrm{LUMO}}$ & $\mathrm{E}_{\text {Total }}$ & $\Delta \mathrm{E}$ \\
\hline $\mathbf{a}$ & -8.3076 & 2.1878 & -6.1198 & 10.4954 & $\bar{i}$ & -8.2440 & 3.5707 & -4.6733 & 11.8146 \\
\hline b & -8.3044 & 3.2746 & -5.0298 & 11.5790 & $\mathbf{j}$ & -8.2783 & 3.4896 & -4.7887 & 11.7678 \\
\hline c & -8.3768 & 3.1350 & -5.2417 & 11.5118 & k & -8.2870 & 3.4520 & -4.8349 & 11.7390 \\
\hline d & -8.7534 & 2.9165 & -5.8368 & 11.6699 & I & -8.1876 & 3.6613 & -4.5263 & 11.8489 \\
\hline e & -8.3090 & 1.6011 & -6.7079 & 9.9101 & m & -8.2821 & 3.4553 & -4.8268 & 11.7374 \\
\hline f & -8.5055 & 1.4847 & -7.0208 & 9.9901 & n & -8.2913 & 3.4621 & -4.8292 & 11.7534 \\
\hline g & -8.3392 & 3.1758 & -5.1634 & 11.5150 & o & -8.2919 & 3.4616 & -4.8303 & 11.7534 \\
\hline h & -8.3632 & 3.2395 & -5.1236 & 11.6027 & & & & & \\
\hline
\end{tabular}

large. So, it could be speculated that the biological activity of these compounds are decided by the $\mathrm{E}_{\mathrm{Lumo}}$ mainly. Because $\mathrm{E}_{\mathrm{LUMO}}$ is related to the ability to accept electronic of a compound. So it could be speculated that, the drug molecules may be accept electrons form receptor.

The $\mathrm{E}_{\text {Lumo }}$ of compounds a-e are low comparatively, it could accept electronic easily, so the biological activity of a-e are higher. The $\mathrm{E}_{\mathrm{Lumo}}$ of $\mathbf{l}$ and $\mathbf{o}$ are high comparatively, it make the weak ability of molecular to accept electronic, so the biological activity of $\mathbf{l}$ and $\mathbf{o}$ are lower. The $\mathrm{E}_{\text {Lumo }}$ of $\mathbf{f}$ is the lowest, the activity is too strong possibly and it is easy to be metabolized in organism, so the biological activity of $\mathbf{f}$ is low. the analyses of theoretical results agree with the experimental data very well.

Table-3 summarizes the main composition of HOMO of most compounds which are in the $\mathrm{N}(19), \mathrm{N}(20)$ and $\mathrm{S}(23)$ and the maximum component is $\mathrm{S}(23)$. The main composition of HOMO of $\mathbf{a}$ are in $\mathrm{C}(12)$ and the main composition of HOMO of $\mathbf{n}$ are in $\mathrm{C}(3)$ and $\mathrm{C}(6)$.

The main composition of LUMO of most compounds are in the $\mathrm{C}(1), \mathrm{C}(2), \mathrm{C}(4), \mathrm{C}(5), \mathrm{C}(15), \mathrm{N}(19)$ and $\mathrm{C}(22)$. When the electron-withdrawing group $\left(-\mathrm{NO}_{2}\right)$ is leaded into compounds $\mathbf{e}$ and $\mathbf{f}$, the main composition of LUMO of $\mathbf{e}$ and $\mathbf{f}$ are added the $\mathrm{N}$ (27), $\mathrm{O}$ (28) and $\mathrm{O}$ (29); and the main composition of LUMO of $\mathbf{a}$ and $\mathbf{n}$ are in S(23). It has been discussed in the previous, that the differences of $\mathrm{E}_{\mathrm{LUMO}}$ may be the main factors to the antimicrobial activity. So, The main composition of
LUMO of compounds may be the active sites; and when the electron-withdrawing group $\left(-\mathrm{NO}_{2}\right)$ is leaded into the compounds, the $-\mathrm{NO}_{2}$ may be the active sites to compounds.

Natural charge: The atom natural charge of compounds are given in Table-4. Data show that the negative charge is mainly concentrated in the $\mathrm{C}(1), \mathrm{N}(19), \mathrm{N}(20), \mathrm{S}(23)$ and $\mathrm{N}(24)$; and the positive charge is mainly concentrated in the $\mathrm{C}(15)$ and $\mathrm{C}(22)$ which is adjoining with the hetero atom and the positive charge is large, showing a strong electronwithdrawing effect, so $\mathrm{C}(15)$ and $\mathrm{C}(22)$ are the active sites of compounds. When the electron-withdrawing group $\left(-\mathrm{NO}_{2}\right)$ is leaded into compounds $\mathbf{e}$ and $\mathbf{f}$, the positive charge of $\mathrm{N}(27)$ of $-\mathrm{NO}_{2}$ is large, so $\mathrm{N}(27)$ is the active sites of $\mathbf{e}$ and $\mathbf{f}$.

Correlation analysis: The SPSS statistical software was used to correlation analysis. The independent variables are the parameters in Table- 1 and the dependent variables are antibacterial activity. The correlation coefficient in Table-5.

Regression analysis: The QSAR of the phenylpropyl aldehyde thiosemicarbazone compounds was studied, the higher correlation parameters of Table- 1 was selected as independent variables and antibacterial activity as the dependent variable $(\mathrm{Y})$ to be stepwise linear regression analysis. The model (1) as follows:

$$
\begin{gathered}
\mathrm{Y}=-10.172 \mathrm{P}+0.392 \mathrm{~V}+1.599 \mathrm{R}-117.940 \\
\mathrm{n}=15, \mathrm{R}=0.803, \mathrm{Se}=0.886, \mathrm{~F}=6.677, \mathrm{Q}=0.906
\end{gathered}
$$

$\mathrm{n}$-The number of samples in the model; R-Multiple correlation coefficient. 


\begin{tabular}{|c|c|c|c|c|c|c|c|c|c|c|c|c|c|}
\hline \multicolumn{14}{|c|}{$\begin{array}{r}\text { TABLE-3 } \\
\text { MAIN COMPOSITION AND PROPORTION OF FF }\end{array}$} \\
\hline Compd. & \multicolumn{7}{|c|}{ HOMO } & \multicolumn{6}{|c|}{ LUMO } \\
\hline $\mathbf{a}$ & \multicolumn{7}{|c|}{$\begin{array}{l}\mathrm{C}(2) 6.39, \mathrm{C}(3) 3.36, \mathrm{C}(4) 8.90, \mathrm{C}(5) 2.69, \mathrm{C}(6) 5.60, \mathrm{C}(12) 57.28, \\
\mathrm{C}(15) 3.53\end{array}$} & \multicolumn{6}{|c|}{$\mathrm{C}(15) 5.01, \mathrm{~N}(19) 6.66, \mathrm{C}(22) 44.38, \mathrm{~S}(23) 31.36, \mathrm{~N}(24) 2.23$} \\
\hline b & \multicolumn{7}{|c|}{$\begin{array}{l}\mathrm{C}(15) 3.38, \mathrm{~N}(19) 1.34, \mathrm{~N}(20) 11.86, \mathrm{C}(22) 2.45, \mathrm{~S}(23) 74.25, \mathrm{~N}(24) \\
6.02\end{array}$} & \multicolumn{6}{|c|}{$\begin{array}{l}\mathrm{C}(1) 14.95, \mathrm{C}(2) 23.54, \mathrm{C}(4) 13.83, \mathrm{C}(5) 21.57, \mathrm{C}(15) 4.67, \\
\mathrm{~N}(19) 3.67, \mathrm{C}(22) 2.88, \mathrm{Cl}(27) 2.30\end{array}$} \\
\hline c & \multicolumn{7}{|c|}{$\begin{array}{l}\mathrm{C}(3) 2.77, \mathrm{C}(6) 2.91, \mathrm{C}(12) 6.92, \mathrm{C}(15) 9.56, \mathrm{~N}(19) 12.23, \\
\mathrm{~N}(20) 12.27, \mathrm{C}(22) 26.10, \mathrm{~S}(23) 6.20, \mathrm{~N}(24) 6.37, \mathrm{Cl}(27) 3.57\end{array}$} & \multicolumn{6}{|c|}{$\begin{array}{l}\mathrm{C}(1) 11.16, \mathrm{C}(3) 13.73, \mathrm{C}(4) 11.53, \mathrm{C}(6) 13.74, \mathrm{C}(12) 4.32, \\
\mathrm{C}(15) 13.44, \mathrm{~N}(19) 10.84, \mathrm{C}(22) 8.26\end{array}$} \\
\hline d & \multicolumn{7}{|c|}{$\mathrm{C}(15) 3.93, \mathrm{~N}(19) 2.70, \mathrm{~N}(20) 15.29, \mathrm{~S}(23) 68.29, \mathrm{~N}(24) 5.80$} & \multicolumn{6}{|c|}{$\mathrm{C}(1) 17.16, \mathrm{C}(2) 26.30, \mathrm{C}(4) 16.17, \mathrm{C}(5) 22.41, \mathrm{Cl}(8) 3.19$} \\
\hline $\mathbf{e}$ & \multicolumn{7}{|c|}{$\mathrm{C}(15) 3.37, \mathrm{~N}(20) 11.86, \mathrm{C}(22) 2.47, \mathrm{~S}(23) 74.20, \mathrm{~N}(24) 6.03$} & \multicolumn{6}{|c|}{$\begin{array}{l}\mathrm{C}(1) 16.63, \mathrm{C}(2) 2.21, \mathrm{C}(3) 10.02, \mathrm{C}(4) 12.95, \mathrm{C}(5) 9.99, \mathrm{C}(6) 2.38 \\
\mathrm{~N}(27) 17.55, \mathrm{O}(28) 11.80, \mathrm{O}(29) 11.74\end{array}$} \\
\hline f & \multicolumn{7}{|c|}{$\mathrm{C}(15) 3.34, \mathrm{~N}(20) 11.64, \mathrm{C}(22) 2.62, \mathrm{~S}(23) 74.18, \mathrm{~N}(24) 6.33$} & \multicolumn{6}{|c|}{$\begin{array}{l}\mathrm{C}(1) 9.69, \mathrm{C}(3) 16.48, \mathrm{C}(5) 9.69, \mathrm{C}(6) 13.25, \mathrm{C}(13) 4.95, \\
\mathrm{~N}(27) 16.34, \mathrm{O}(28) 11.35, \mathrm{O}(29) 11.35\end{array}$} \\
\hline $\mathbf{g}$ & \multicolumn{7}{|c|}{$\mathrm{C}(15) 3.64, \mathrm{~N}(20) 12.34, \mathrm{C}(22) 2.53, \mathrm{~S}(23) 73.45, \mathrm{~N}(24) 5.95$} & \multicolumn{6}{|c|}{$\begin{array}{l}\mathrm{C}(1) 19.53, \mathrm{C}(2) 12.99, \mathrm{C}(4) 17.65, \mathrm{C}(5) 12.09, \mathrm{C}(15) 8.42, \\
\mathrm{~N}(19) 6.65, \mathrm{C}(22) 5.45\end{array}$} \\
\hline $\mathbf{h}$ & \multicolumn{7}{|c|}{$\mathrm{C}(15) 3.38, \mathrm{~N}(20) 11.84, \mathrm{C}(22) 2.49, \mathrm{~S}(23) 74.21, \mathrm{~N}(24) 6.08$} & \multicolumn{6}{|c|}{$\begin{array}{l}\mathrm{C}(1) 14.64, \mathrm{C}(2) 15.18, \mathrm{C}(4) 15.20, \mathrm{C}(5) 14.63, \mathrm{C}(15) 10.42, \\
\mathrm{~N}(19) 8.15, \mathrm{C}(22) 6.68\end{array}$} \\
\hline $\mathbf{i}$ & \multicolumn{7}{|c|}{$\mathrm{C}(15) 3.42, \mathrm{~N}(20) 12.11, \mathrm{C}(22) 2.35, \mathrm{~S}(23) 74.14, \mathrm{~N}(24) 5.78$} & \multicolumn{6}{|c|}{$\begin{array}{l}\mathrm{C}(1) 4.41, \mathrm{C}(2) 2.52, \mathrm{C}(4) 4.50, \mathrm{C}(5) 2.34, \mathrm{C}(15) 26.38, \mathrm{~N}(19) 17.83, \\
\mathrm{C}(22) 19.93, \mathrm{~S}(23) 6.55, \mathrm{~N}(24) 5.43\end{array}$} \\
\hline $\mathbf{j}$ & \multicolumn{7}{|c|}{$\mathrm{C}(15) 3.39, \mathrm{~N}(20) 11.90, \mathrm{C}(22) 2.41, \mathrm{~S}(23) 73.80, \mathrm{~N}(24) 5.91$} & \multicolumn{6}{|c|}{$\begin{array}{l}\mathrm{C}(4) 3.24, \mathrm{C}(15) 27.51, \mathrm{~N}(19) 19.15, \mathrm{C}(22) 19.91, \mathrm{~S}(23) 6.64, \\
\mathrm{~N}(24) 5.47\end{array}$} \\
\hline $\mathbf{k}$ & \multicolumn{7}{|c|}{$\mathrm{C}(15) 3.40, \mathrm{~N}(20) 11.94, \mathrm{C}(22) 2.41, \mathrm{~S}(23) 74.11, \mathrm{~N}(24) 5.93$} & \multicolumn{6}{|c|}{$\begin{array}{l}\mathrm{C}(1) 5.29, \mathrm{C}(2) 5.90, \mathrm{C}(4) 5.79, \mathrm{C}(5) 6.17, \mathrm{C}(15) 23.11, \mathrm{~N}(19) 16.53, \\
\mathrm{C}(22) 16.45, \mathrm{~S}(23) 5.52, \mathrm{~N}(24) 4.53\end{array}$} \\
\hline l & $\mathrm{C}(15) 3.3$ & $\mathrm{~N}(20) 1$ & $42, \mathrm{C}(22)$ & $13, \mathrm{~S}(23$ & $99.16, \mathrm{~N}(2$ & 5.28 & & 9) $19.97, \mathrm{C}$ & 22) 23.62 & $(23) 7.6$ & $\mathrm{~N}(24) 6$. & & \\
\hline $\mathbf{m}$ & $\mathrm{C}(15) 3.4$ & $\mathrm{~N}(20) 1$ & $90, \mathrm{C}(22)$ & $40, \mathrm{~S}(23$ & $3.81, \mathrm{~N}$ & 4) 5.90 & & $\begin{array}{l}63, \mathrm{C} \\
15.81\end{array}$ & $\begin{array}{ll}96, \mathrm{C}( \\
3) 5.30\end{array}$ & $\begin{array}{ll}18, \mathrm{C}( \\
24) 4.3\end{array}$ & $3, \mathrm{C}($ & 20, & 15.92 \\
\hline $\mathbf{n}$ & $\begin{array}{l}\mathrm{C}(1) 7.52 \\
\mathrm{C}(13) 4.8\end{array}$ & $\mathrm{C}(2) 6.84$ & (3) 25.3 & $(4) 7.2$ & (5) 7.1 & (6) 25.42 , & & $5) 3.67, \mathrm{~N}$ & 0) 19.60 , & (22)3.07 & $(23) 44.5$ & $\mathrm{~N}(24) 16$ & \\
\hline $\mathbf{o}$ & $\mathrm{C}(15) 3$ & $\mathrm{C}(22) 2$ & $2, \mathrm{~S}(23) 7$ & $19, \mathrm{~N}(24$ & .96 & & & $\begin{array}{l}1.15, \mathrm{C} \\
18.57 \\
\end{array}$ & $\begin{array}{l}37, \mathrm{C} \\
3) 6.22\end{array}$ & $6, \mathrm{C}$ &, $\mathrm{C}$ & 79 , & 8.25 , \\
\hline & & & & & I NA & $\begin{array}{r}\text { TA } \\
\text { AL } \mathrm{CH}\end{array}$ & -4 & MP & & & & & \\
\hline Compd. & C (1) & $\mathrm{C}(2)$ & C (3) & C (4) & C (5) & C (6) & $\mathrm{C}(15)$ & $\mathrm{N}(19)$ & $\mathrm{N}(20)$ & $\mathrm{C}(22)$ & S (23) & $\mathrm{N}(24)$ & $\mathrm{N}(27)$ \\
\hline a & -0.193 & -0.239 & 0.097 & -0.287 & -0.193 & -0.262 & 0.147 & -0.301 & -0.584 & 0.277 & -0.017 & -0.924 & - \\
\hline b & -0.227 & -0.031 & -0.050 & -0.212 & -0.216 & -0.218 & 0.143 & -0.327 & -0.502 & 0.421 & -0.368 & -0.869 & - \\
\hline c & -0.226 & -0.210 & -0.041 & -0.212 & -0.226 & -0.043 & 0.132 & -0.313 & -0.503 & 0.42 & -0.365 & -0.868 & - \\
\hline d & -0.233 & -0.053 & -0.053 & -0.200 & -0.229 & -0.067 & 0.137 & -0.344 & -0.525 & 0.389 & -0.268 & -0.876 & - \\
\hline e & -0.173 & -0.235 & 0.008 & 0.045 & -0.178 & -0.239 & 0.144 & -0. & -0 & 0.421 & -0.367 & -0.869 & 0.662 \\
\hline f & -0.169 & -0.24 & 0.013 & -0.240 & -0.169 & 0.024 & 0.136 & -0.324 & -0.502 & 0.419 & -0.359 & -0.869 & 0.663 \\
\hline g & -0.096 & -0.244 & -0.020 & -0.232 & -0.193 & -0.246 & 0.136 & -0.323 & -0.498 & 0.415 & -0.363 & -0.869 & - \\
\hline h & -0.299 & -0.199 & -0.067 & -0.199 & -0.299 & 0.479 & 0.140 & -0.326 & -0.502 & 0.421 & -0.366 & -0.869 & - \\
\hline $\mathbf{i}$ & -0.271 & 0.348 & -0.083 & -0.206 & -0.239 & -0.212 & 0.148 & -0.332 & -0.502 & 0.423 & -0.372 & -0.870 & - \\
\hline $\mathbf{j}$ & -0.174 & -0.277 & -0.002 & -0.290 & 0.399 & -0.344 & 0.143 & -0.327 & -0.502 & 0.422 & -0.369 & -0.869 & - \\
\hline k & -0.325 & -0.188 & -0.084 & -0.193 & -0.272 & 0.379 & 0.142 & -0.328 & -0.502 & 0.422 & -0.369 & -0.869 & - \\
\hline I & -0.372 & -0.155 & -0.136 & 0.419 & -0.384 & 0.416 & 0.148 & -0.331 & -0.502 & 0.423 & -0.375 & -0.869 & - \\
\hline $\mathbf{m}$ & -0.325 & -0.187 & -0.086 & -0.192 & -0.274 & 0.383 & 0.142 & -0.328 & -0.502 & 0.422 & -0.375 & -0.869 & - \\
\hline n & -0.218 & -0.215 & -0.050 & -0.215 & -0.218 & -0.036 & 0.142 & -0.328 & -0.502 & 0.422 & -0.369 & -0.869 & - \\
\hline o & -0.216 & -0.215 & -0.049 & -0.216 & -0.214 & -0.036 & 0.142 & -0.327 & -0.502 & 0.422 & -0.369 & -0.869 & - \\
\hline
\end{tabular}

TABLE-5

CORRELATION COEFFICIENT BETWEEN THE PARAMETERS AND THE RATE OF INHIBITION

\begin{tabular}{ccccccccccc}
\hline & $\mathrm{E}_{\mathrm{n}}$ & $\mathrm{E}_{\mathrm{n}+1}$ & $\Delta \mathrm{E}$ & $\mathrm{E}_{\text {Total }}$ & $\mathrm{E}_{\mathrm{n}-1}$ & $\mathrm{R}$ & $\mathrm{P}$ & $\mathrm{V}$ & $\log \mathrm{P}$ & $\mathrm{SG}$ \\
\hline $\mathrm{Y}$ & -0.107 & 0.355 & 0.281 & -0.182 & 0.507 & 0.680 & 0.620 & 0.692 & 0.109 & 0.679 \\
\hline
\end{tabular}

Se-Standard deviation F-sher's statistics; Q-Quality factor $(\mathrm{Q}=\mathrm{R} / \mathrm{Se})$

\section{Conclusions}

(1) The characteristics of LUMO are the main factors to influence antibacterial activities of these kinds of compounds. The mechanism is that receptor provide electronic to the compounds.

(2) The results indicate that $\mathrm{C}(15)$ and $\mathrm{C}(22)$ of compounds might be the important active site; When the electron-withdrawing group $\left(-\mathrm{NO}_{2}\right)$ is leaded into compounds, the $\mathrm{N}$ of $-\mathrm{NO}_{2}$ is the active sites too.

(3) The molecular polarizability (P), Molecular molar refractive index $(\mathrm{R})$ and molecular volume $(\mathrm{V})$ have great relevance with antibacterial activity of these compounds.

\section{ACKNOWLEDGEMENTS}

This project was supported by the Science and Technology projects of Hebei Province (Contract No. 10273939). 


\section{REFERENCES}

1. R.A. Finch, M.C. Liu, S.P. Grill, W.C. Rose, R. Loomis, K.M. Vasquez, Y.-C. Cheng and A.C. Sartorelli, Biochem. Pharmacol., 59, 983 (2000).

2. A. Walcourt, M. Loyevsky, D.B. Lovejoy, V.R. Gordeuk and D.R. Richardson, Int. J. Biochem. Cell Biol., 36, 401 (2004).

3. J.R. Chopra, U.U.S.A. Divya and S.K. Gupta, Asian J. Chem., 12, 1277 (2000).

4. J. Shim, J.N. Rama and F.N.A. Mohammad, Asian J. Chem., 25, 5838 (2013).

5. C.N. Hancock, L.H. Stockwin, B. Han, R.D. Divelbiss, J.H. Jun, S.V. Malhotra, M.G. Hollingshead and D.L. Newton, Free Radic. Biol. Med., 50, 110 (2011)
6. S.X. Wang, C. Liu and J. Duan, Asian J. Chem., 23, 4451 (2011).

7. D.K. Saha, B.K. Das, S. Chandra and B.K. Datta, J. Pharm. Res. Opin., 2, 125 (2012).

8. P. Chellan, S. Nasser, L. Vivas, K. Chibale and G.S. Smith, J. Organomet. Chem., 695, 2225 (2010).

9. Y. Xu, Z. Wang, Y. Ling, W. Dong, J. Xing, P. Liang and X. Yang, Chinese J. Org. Chem., 32, 1278 (2012).

10. T.B. Wei, Y.L. Leng, Y.C. Wang, J.H. Zhang and Y.M. Zhang, Chinese J. Org. Chem., 29, 216 (2009).

11. G.F. Yang, H.Y. Liu, H.Z. Yang and X.F. Yang, Acta Chim. Sin., 56, 729 (1998).

12. D.B. Zhang, Y.H. Ren, D.W. Fu, B. Yan, J.-R. Song and X.Q. Lu, Acta Chim. Sin., 66, 2409 (2008). 